\title{
AQAD NIKAH PESPEKTIF FIQH DAN KOMPILASI HUKUM ISLAM
}

\author{
Muhazir \\ Dosen Hukum Islam Fakultas Syariah IAIN Langsa \\ muhazir@iainlangsa.ac.id
}

\begin{abstract}
Abtract. Regulations relating to private matters such as marriage and other civil matters are regulated in such a way as to achieve the objectives of the law itself. Therefore, how important is the position of law in the social order. Likewise in the concept of marriage, in order to regulate and protect and protect human rights, it is necessary to make a formal legal codification in order to have legal power that can guarantee each individual. Especially in this marriage concerning private matters which are very urgent to protect, this is due to factors arising from family problems, both concerning the protection of his wife, husband and children. Aqad marriage in marriage has an important role in determining the legal or illegitimate marriage, because aqan is a binding bond both legally and morally between two individuals.
\end{abstract}

Keywords: marriage, Aqad

\begin{abstract}
Abtrak. Peraturan-peratuan yang berkenaan dengan hal privat seperti pernikahan dan masalah keperdataan lainnya, diatur sedemikian rupa untuk mencapai tujuan dari hukum itu sendiri. Oleh karena itu, betapa pentingnya kedudukan hukum dalam tatanan sosial. Begitu juga halnya dalam konsep perkawinan, untuk menertibkan dan menjaga serta melindungi hak-hak bagi manusia perlu dilakukan kodifikasi hukum yang bersifat formal agar memiliki kekuatan hukum yang dapat menjamin tiap individu. Khususnya dalam pernikahan ini menyangkut hal privat yang sangat urgen sekali dilindungi, hal ini dikarenakan oleh factor-faktor yang timbul dari problematika-problematika keluarga, baik menyangkut perlindungan terhadap istri, suami dan anak. Aqad nikah dalam perkawinan memiliki peran penting dalam penentuan sah atau tidak sahnya perkawinan, karena aqan merupakan suatu ikatan yang mengikat baik secara hukum maupun moral antara dua individu.
\end{abstract}

\section{Kata Kunci: Perkawinan, Aqad}

\section{Pendahuluan}

Perkawinan dan keluarga membentuk corak masyarakat yang khas. Sistem perkawinan yang telah dibuat diharapkan mampu menjadikan hubungan antara laki-laki dan perempuan dalam penuh kehormatan dan saling meridhoi. Perkawinan merupakan jalan dan saluran yang paling baik dan selamat bagi syahwat sebagai naluri manusia untuk selanjutnya melahirkan dan memelihara generasi baru dengan baik dan juga akan menciptakan kondisi dan suasana yang tertib dan aman dalam kehidupan sosial.

Ketentuan-ketentuan mengenai perkawinan menurut syari'at Islam yang mengikat setiap muslim, artinya setiap muslim wajib menundukkan diri secara penuh kepadanya. Lebih jauh dari itu, setiap muslim perlu selalu menyadari bahwa di dalam perkawinan terkandung nilai-nilai ibadah, yang memiliki ikatan erat atau mitsaaqan 
ghalidzan sebagimana yang telah dijelaskan dalam UU No 1 Tahun 1974 Tentang Perkawinan. ${ }^{1}$

Perkawinan dianggap sangat penting untuk diatur agar tertata sebuah mekanisme hukum yang memadai, sehingga hal ini menggugah pemerintah untuk menjadikan suatu peraturan yang mengandung asas-asas Islam agar bisa memiliki nilai formal sehingga diakui oleh pemerintah.

Formalisasi hukum Islam khususnya di bidang perkawinan dibentuk dalam sebuah peraturan Negara yang dikemas dalam UU No 1 Tahun 1974 Tentang Perkawinan, serta harapan dari semua itu adalah untuk menjaga stabilitas dan kekuatan hukum serta perlindungan bagi masyarakat Islam untuk melangsungkan pernikahan yang diakui oleh Negara, karena Indonesia adalah negara hukum, sehingga segala sesuatu tindakan yang dilakukan oleh warga negara indonesia memiliki aturan hukum, begitu juga dalam hal perkawinan.

Upaya tranformasi hukum Islam ke dalam Undang-Undang pada dasarnya banyak menuai kontroversi dari kalangan masyarakat sendiri, karena banyaknya problem dari aspek materil yang dirasa belum memadai dan menjawab permasalahan tentang perkawinan.

Kegiatan merumuskan norma-norma

1 Dalam pasal Pasal 1 dijelaskan bahwa "Perkawinan adalah ikatan lahir batin antara seorang pria dan seorang wanita sebagai suami istri dengan tujuan membentuk keluarga atau rumah tangga yang bahagia dan kekal berdasarkan Ketuhanan Yang Maha Esa. hukum Islam yang terdapat dalam al-Quran, al-Sunnah, dan kitab-kitab fiqh klasik menjadi suatu aturan yang bersifat umum, tidak memihak pada salah satu pola pemikiran, bersifat mengikat dan memaksa yang diberlakukan dan sesuai dengan kondisi masyarakat Indonesia.

Sistem perkawinan yang telah dibuat diharapkan mampu menjadikan hubungan antara laki-laki dan perempuan dalam penuh kehormatan dan saling meridhoi. Perkawinan merupakan jalan dan saluran yang paling baik dan selamat bagi syahwat sebagai naluri manusia untuk selanjutnya melahirkan dan memelihara generasi baru dengan baik dan juga akan menciptakan kondisi dan suasana yang tertib dan aman dalam kehidupan sosial.

Dalam perspektif hukum islam, nikah atau kawin secara etimologi (lughah) berarti kumpul atau bersatu, sedangkan secara terminologisnya (istilah) berarti 'aqd (ikatan) yang menghalalkan hubungan laki-laki dan perempuan yang semula terlarang. ${ }^{2}$

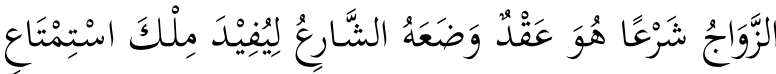

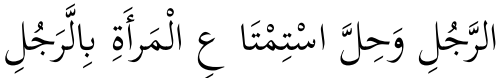

Artinya : Perkawinan menurut syara' yaitu akad yang ditetapkan syara' untuk membolehkan bersenang-senang antara lakilaki dengan perempuan dan menghalalkan

\footnotetext{
${ }^{2}$ Muhammad bin Ahmad Al-Ramli, Ghayah AlBayan Syarh Zubad Ibn Raslan, ( Beirut : Dar AlKutub Al-Islamiyah, 2012),363
} 
bersenang-senangnya perempuan dengan lakilaki. $^{3}$

Jika melihat kepada hakikat dari akad itu bila dihubungkan dengan kehidupan suami istri yang berlaku sesudahnya, yaitu boleh bergaul, sedangkan sebelum akad tersebut berlangsung diantara keduanya tidak boleh bergaul. Yang dimaksudkan membolehkan hubungan kelamin itu, karena pada dasarnya hubungan laki-laki dan perempuan itu adalah terlarang, kecuali ada hal-hal yang membolehkan secara hukum syara'. Diantara hal yang membolehkan bergaulnya laki-laki dan perempuan adalah adanya akad nikah diantara keduanya. Dengan demikian, akad nikah itu merupakan suatu usaha untuk membolehkan sesuatu yang asalnya tidak boleh. ${ }^{4}$

Pengertian tersebut tampaknya dibuat hanya untuk melihat dari satu segi saja, yaitu kebolehan hukum dalam berhubungan antara seorang laki-laki dengan seorang perempuan, yang semula hukumnya dilarang menurut syara' menjadi halal. Pernikahan dikatakan sah apabila terjadi antara seorang pria dan seorang wanita dengan terpenuhinya semua syarat dan rukunnya menyebabkan semua hubungan keduanya menjadi halal bahkan berpahala, yang sebelumnya hukumnya

\footnotetext{
${ }^{3}$ Abd. Rahman al-Ghazaly, Fikih Munakahat, (Jakarta:Kencana, 2006), 8 dan Abu Bakr Al-Jabir AlJazairi, Minhaju Al-Muslim, (Madinah : Maktabah AlUlum wa Al-Hikam, 2012),301

${ }^{4}$ Amir Syarifuddin. Hukum Perkawinan Islam Di Indonesia. (Jakarta: Kencana. 2007). 37
}

adalah haram dan berdosa. Maksud dari hubungan yang semula terlarang (haram) antara laki-laki dan perempuan itu adalah berduaan, bertatapan, bersentuhan, bermesraan, berkasih sayang, berhubungan badan dan seterusnya. ${ }^{5}$

\section{Terminologi Nikah Perspektif Hukum Islam}

Perkawinan atau pernikahan dalam literatur fiqh berbahasa arab disebut dengan dua kata yaitu; nikah (نكاح) dan zawaj (زواج). Kata nakaha dalam Al Qur'an dengan arti kawin terdapat didalam surat An Nisa ayat 3:
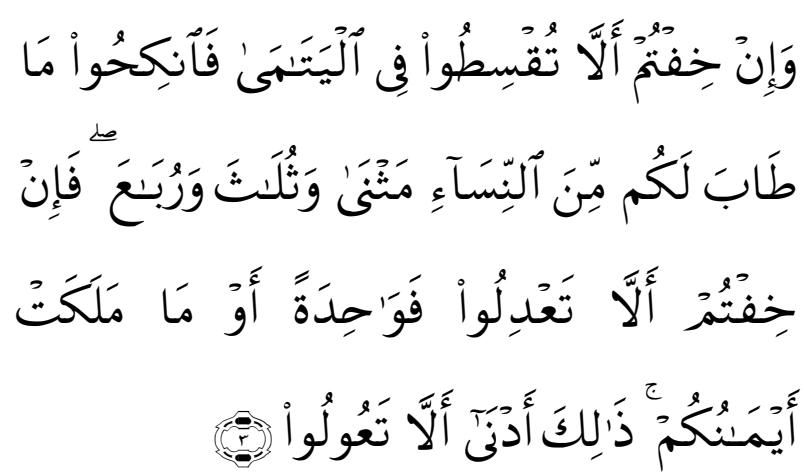

Dan jika kamu takut tidak akan dapat Berlaku adil terhadap (hak-hak) perempuan yang yatim (bilamana kamu mengawininya), Maka kawinilah wanita-wanita (lain) yang kamu senangi : dua, tiga atau empat. kemudian jika kamu takut tidak akan dapat Berlaku adil,

\footnotetext{
${ }^{5}$ Umay M. Dja'far Shiddieq, Indahnya Keluarga Sakinah Dalam Naungan Al-Qur'an dan Sunnah, (Jakarta: Zakia Press, 2004), 2

${ }^{6}$ Dalam kitab-kitab fiqh sebagian pengarangnya menggunakan kata al-nikah dan ada yang menggunakan kata al-zawaj. Yang menggunakan kata al-zawaj seperti dalam kitab fiqh sunnah karangan Sayyid Sabiq, sedangkan yang menggunakan kata nikah sengatlah banyak, seperti dalam kitab Zubad karangan Ahmad Al-Ramli, Bidayatul Mujtahid karangan Ibn Rusy, Fiqh 'Ala Al-Mazhab Al-Arba'atu karangan Abdurahman Al-Jaziri. Dan sebagainya. Sedangankan dalam bahasa arab kata nikah atau pernikahan yaitu Nakaha dan Al-Zawaj. Lihat A.W. Munawwir, Kamus Al-Munawwir Indonesia Dan Arab, (Surabaya : Pustaka Progressif, 2007),650
}

Aqad Nikah Pespektif Fiqh Dan Kompilasi Hukum Islam | 23 
Maka (kawinilah) seorang saja, atau budakbudak yang kamu miliki. yang demikian itu adalah lebih dekat kepada tidak berbuat aniaya. $^{7}$

Kemudian kata zawaj dalam Al Qur'an dalam arti kawin terdapat surat Al Ahzab ayat $37:^{8}$
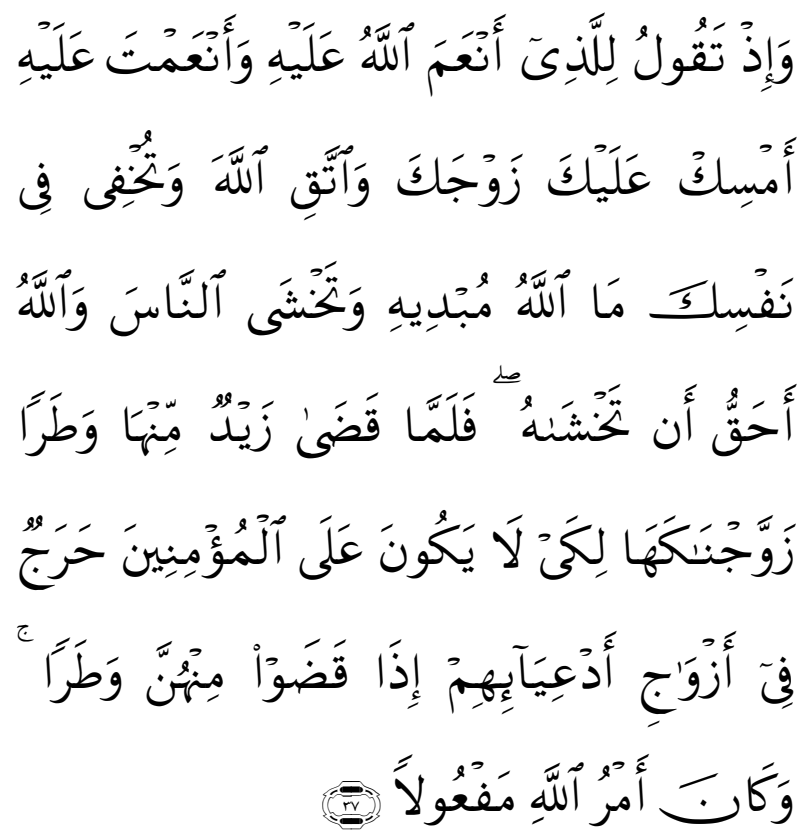

Dan (ingatlah), ketika kamu berkata kepada orang yang Allah telah melimpahkan nikmat kepadanya dan kamu (juga) telah memberi nikmat kepadanya: "Tahanlah terus isterimu dan bertakwalah kepada Allah", sedang kamu Menyembunyikan di dalam hatimu apa yang Allah akan menyatakannya, dan kamu takut kepada manusia, sedang Allah-lah yang lebih berhak untuk kamu takuti. Maka tatkala Zaid telah mengakhiri keperluan terhadap Istrinya (menceraikannya), Kami kawinkan kamu dengan dia supaya tidak ada keberatan bagi orang mukmin untuk (mengawini) isteri-isteri anak-anak angkat mereka, apabila anak-anak angkat itu telah menyelesaikan keperluannya daripada isterinya dan adalah ketetapan Allah itu pasti terjadi. ${ }^{9}$

\footnotetext{
${ }^{7}$ Kementerian Agama RI. Al-Quran Keluarga, ( Bandung : Fitrah Rabbani, 2009),77

${ }^{8}$ Amir Syarifuddin, Hukum Perkawinan Islam di Indonesia, (Jakarta : Kencana 2007),35 Keluarga,.419
}

Dari ayat-ayat diatas menunjukan bahwa Pada dasarnya semua hubungan khususnya dalam pernikahan adalah kebutuhan manusia bahkan seluruh makhluk hidup. Akan tetapi, sebagai manusia terlebih lagi kita sebagai umat Islam yang memiliki akal budi, norma, etika dalam berhubungan dengan tuhan dan dengan sesama manusia, maka kita memiliki batasan-batasan tertentu yang dilarang oleh Allah SWT untuk dilakukan oleh laki-laki dan perempuan yang belum menikah. Berdasarkan hal inilah Allah menentukan tatacara agar laki-laki menjadi halal berhubungan dengan wanita.

\section{Ketentuan Hukum Pernikahan}

Dalam hal pernikahan meskipun dianjurkan, namun ada beberapa hukum yang harus diperhatikan bagi siapa saja nikah itu peruntuhkan. Pada dasarnya nikah merupakan salah satu bentuk ibadah yang diperintahkan kepada manusia tanpa terkecuali. Karena dengan menikah, manusia dapat menjaga diri dari hal-hal yang tidak disukai oleh Allah. Rasulullah telah mencontohkan bahwa pernikahan adalah seatu bentuk ibadah yang disyari'atkan oleh allah, sebagaimana yang telah difirman dalam [QS. Al-Ra'd. 13:38]

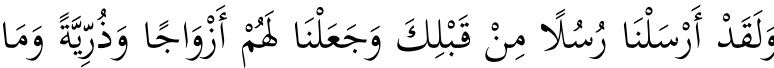

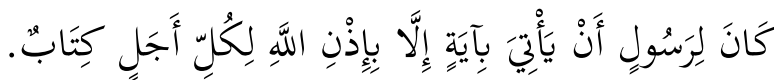

Dan sesungguhnya Kami telah mengutus beberapa Rasul sebelum kamu dan Kami memberikan kepada mereka isteri-isteri dan 
keturunan. Dan tidak ada hak bagi seorang Rasul mendatangkan sesuatu ayat (mukjizat) melainkan dengan izin Allah. Bagi tiap-tiap masa ada Kitab (yang tertentu). ${ }^{10}$

Meskipun dalam beberapa ayat dan hadis menjelaskan bahwa anjuran untuk menikah, tetapi ketentuan ini tidak bisa diberlakukan semerta-merta tanpa melihat aspek-aspek yang lain. Ada beberapa hukum nikah yang telah dirumuskan oleh para ulama fiqh, namun pada prinsipnya mayoritas ulama berpendapat bahwa hukum nikah adalah sunat, dari ulama zhahiriah menyatakan bahwa hukum nikah adalah wajib. ${ }^{11}$ Pada perkembangannya hukum nikah terdiri dari lima yaitu wajib, haram, makruh, sunnah. Ibahah (boleh/mubah) antara lain $;^{12}$

Pertama, wajib dalam hal ini berlaku bagi seseorang yang sudah mampu untuk melakukannya (secara finansial dan fisikal) dan keinginannya untuk menyalurkan hasrat seksual sangat kuat, sementara itu ia khawatir terjerumus dalam perzinaan apabila tidak menikah, maka hukum pernikahan adalah wajib. Seperti halnya hadits riwayat jama'ah dari Ibnu Mas'ud bahwa Rasulullah SAW bersabda :

11 Ibnu Rusydi Al-Qurtubi Al-Andalisia, Bidayatul Mujtahid Wa Nihayatu Al-Muqashid, (Mesir : Maktabah Al-Syuruqu Al-Dauliah, 2004), 380

12 'Abdurahman Al-Jaziri, Kitab Al-fIqh 'Ala AlMazdahib Al-Arba'ah, ( Beirut : Dar Al-Kutub Al'Ilmiyah, 1986),3

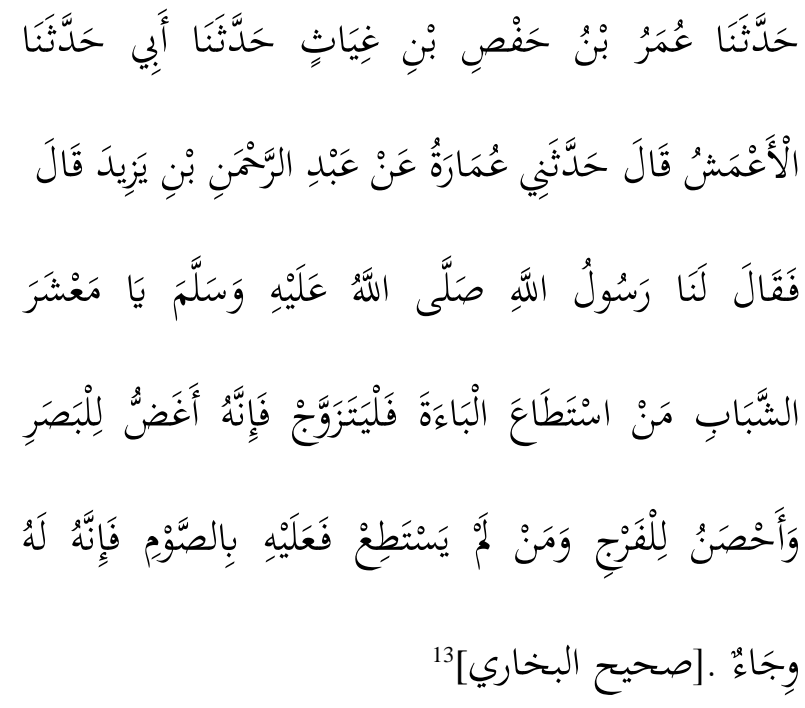

Telah bercerita kepada kami 'Umar bin Hafsi bin Ghiyast telah bercerita kepada kami ayahku telah bercerita kepada kami AlA'masy berkata A'masy telah bercerita kepada kami 'Umarah dari 'Abdi Al-Rahman bin Yazid berkata. Telah bersabda kepada kami Rasulullah SAW "Wahai pemuda jika diantara kamu ada yang mampu menikah hendaklah ia menikah karena matanya akan lebih terjaga dan kemaluannya akan lebih terpelihara. Jika ia belum mampu menikah, hendaklah ia berpuasa karena puasa itu ibarat mengebiri".

Kedua, sunnah bagi orang yang sudah bergejolak dan mampu menikah, namun masih dapat menahan dirinya dari berbuat zina, maka hukum baginya adalah sunnah. Namun tidak dibenarkan juga jika seseorang tidak ingin meninakah, karena pada prinsipnya menikah lebih utama dari pada menenggelamkan diri dalam ibadah karena menjalani hidup bagaikan pendeta sedikitpun tidak dibenarakan dalam Islam.

13 'Abdullah Muhammad bin Isma'il AlBukhari, Shahih Al-Bukhari, Juz 3 ( Bairut : Dar AlFikr, 1981), 117 
عن أبى أمامة أن النبي صلى الله عليه وسلم قال تزوجوا

فإنى مكا ثر بكم الأمم ولاتكونوا كا لرهبا نية

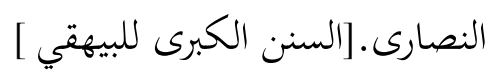

Dari Abi Umamah bahwa Nabi SAW bersabda "Menikahlah kalian, karena aku akan membanggakan banyaknya jumlah kalian pada umat-umat lain. Janganlah kalian hidup seperti pendeta-pendeta nasrani."

Dalam hadis yang lain juga dijelaskan bahwa nikah merupakan bentuk kesunnahan. Hal ini diterangkan dalam hadis Nabi SAW :

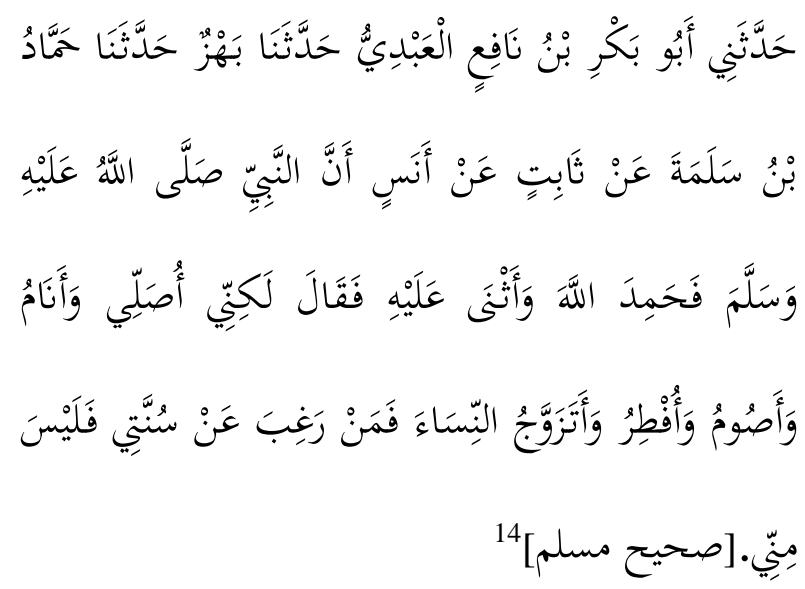

Telah bercerita kepada kami Abu Bakr bin Nafi' Al-'Abdiyu telah bercerita kepada kami Bahzu telah bercerita kepada kami Hammadu bin Salamah dari Stabit dari Anas bahwasanya Nabi SAW memuji allah dan menyanjungnya, kemudian beliau bersabda "akan tetapi aku sembahyang dan tidur dan puasa dan berbuka dan menikahi perempuan maka barangsiapa tidak suka akan sunnahku, maka ia bukan dari golongan ku".

Ketiga, Pernikahan menjadi haram bagi siapa saja yang mengetahui dirinya tidak memiliki kemampuan untuk memenuhi

14 Ibn Hajar Al-'Asqalani, Bulughul Maram, ( Beirut : Dar Al-Kutub Al-Islamiyah, 2002),222 dan Muhammad Fua'd 'Abdu Al-Baqi, Shahih Muslim, Juz 2 ( Indonesia : Maktabah Dahlan, tt), 16 kewajibannya sebagai suami, baik dalam nafkah lahiriah (bersifat finansial) maupun nafkah batiniah (kemampuan melakukan hubungan seksual) yang wajib diberikan kepada pasangannya. Hendaknya seorang laki-laki maupun perempuan yang akan menikah menyebutkan dengan jujur kekurangan dari dirinya. Jika ternyata salah satu pasangan mengetahui aib pada pasangannya. Maka, dia berhak untuk membatalkan pernikahan tersebut. Jika aib itu pada perempuan, maka calon suami boleh membatalkan dan mengambil kembali mahar yang telah diberikan, dan diharamkan juga menikah jika bertujuan untuk menyakiti pasangannya. Ketentuan ini diqiyaskan dengan firman Allah dalam QS. Al-Baqarah [ 2:195] yang berbunyi ;

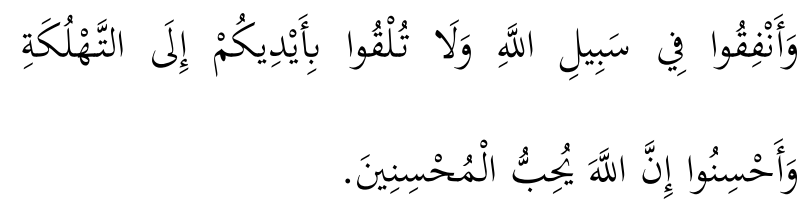

Dan belanjakanlah (harta bendamu) di jalan Allah, dan janganlah kamu menjatuhkan dirimu sendiri ke dalam kebinasaan, dan berbuat baiklah, karena sesungguhnya Allah menyukai orang-orang yang berbuat baik. ${ }^{15}$

Dari ayat diatas menunjukan bahwa nikah merupakan anjuran yang bersifat ibadah sehingga tidak dibolehkan dalam suatu ibadah dilandasi oleh niat atau perbuatan yang merusak, sehingga diharamkan bagi umat Islam ketika hendak menikah dengan tujuan ingin menganiaya atau berbuat dhalim.

Keempat, makruh hukumnya menikah bagi seseorang yang mempunyai kemauan/kemampuan untuk menikah dan cukup mempunyai kemampuan untuk menahan diri sehingga tidak memungkinkan

Keluarga,.30

Kementerian Agama RI, Al-Quran

Aqad Nikah Pespektif Fiqh Dan Kompilasi Hukum Islam | 26 
jatuh dalam perbuatan zina. Hanya saya orang ini tidak memiliki keinginan yang kuat untuk menikah, bagi orang yang seperti ini hukumnya makruh untuk menikah. ${ }^{16}$

Kelima, Ibahah Bagi laki-laki yang tidak terdesak oleh alasan-alasan yang mewajibkan segera menikah atau karena alasan-alasan yang mengharamkan untuk menikah, perkawinan baginya hanya untuk kesenangan bukan untuk menjaga kehormatannya, bagi orang yang seperti ini maka hukumnya mubah. Imam Syafi'i menjelaskan bahwa pada dasarnya hukum nikah adalah ibahah, karena tujuan nikah merupakan untuk mendapatkan kenikmatan. ${ }^{17}$

\section{Akad Nikah Dalam Perspektif Hukum Islam}

Sebelum membahas tentang akad nikah. Maka, terlebih dahulu perlu dicermati tentang kedudukan akad dalam nikah, karena secara khusus akad nikah memiliki perbedaan dengan akad jual beli, meskipun dalam tataran terminologi secara umum memiliki kesamaan makna dan tujuan terhadap suatu hal tertentu. Contoh kecil misalanya, dalam bentuk sighat saja berbeda antara akad nikah dengan akad jual beli meskipun tujuannya sama yaitu untuk dapat memiliki secara sah dimata hukum terhadap kepemilikan sesuatu hal atau barang tertentu.

Kedudukan akad dalam nikah memiliki fungsi yang sangat urgen sekali, karena akad merupakan salah satu bentuk dari rangkaian unsur dalam rukun pernikahan. ${ }^{18}$ Unsur akad dalam pernikahan yaitu terpenuhi ijab dan qabul yang menghendaki adanya dua pihak yang berakad. Secara umum akad sendiri

\footnotetext{
16 'Abdurahman Al-Jaziri, Kitab Al-fIqh 'Ala AlMazdahib Al-Arba'ah,. 5

17 'Abdurahman Al-Jaziri, Kitab Al-fIqh 'Ala AlMazdahib Al-Arba'ah,.7

${ }^{18}$ Zainuddin bin 'Abdul 'Aziz Al-Malibari, Fathul Mu'in, (Jakarta : Dar Al-Kutub AlIslamiyah,2010),202
}

memiliki tiga (3) rukun, yaitu ; 'aqid (subjek), ma'qud 'alaih ( objek) dan shighat. ${ }^{19}$ Berdeda dengan Hanafiyah yang menyatakan bahwa rukun akad yaitu ijab dan qabul, pendapat ini sesuai dengan definisi rukun menurut ulama kalangan Hanafiyah yaitu sesuatu yang hadirnya sesuatu yang lain bergantung kepadanya dan sesuatu tersebut merupakan bagian dari hakikatnya. ${ }^{20}$

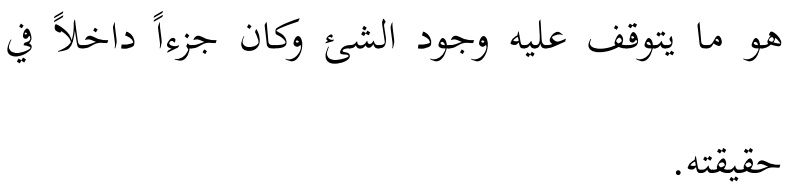

Makna akad secara umum berasal dari bahasa Arab ( العقد ) jama'nya ( العقود ) yang berarti ikatan, mengikat. Dan dapat juga diartikan sebagai العقدة (sambungan), العهد (janji). ${ }^{21}$ Namun secara garis besarnya adalah:

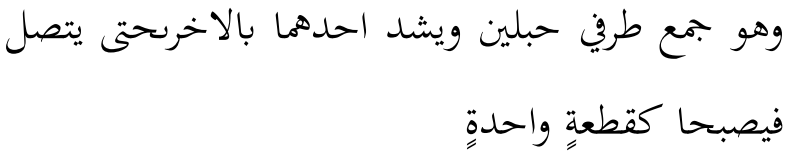

Menghimpun atau mengumpulkan dua ujung tali dan mengikatnya salah satu dari pada yang lainnya hingga keduanya bersambung dan menjadi seperti seutas tali yang satu".

Pengertian lafdiyah ini sebagai mana yang tertulis dalam kitab suci al-Qur'an QS. Al-Maidah. [5:1] yang berbunyi:

19 Ali Yusuf As-Subki, Fiqh Keluarga, diterjemahkan oleh Nur Khizim. (Jakarta : AMZAH, 2010), 99

20 Wahbah Zuhaili, Fiqh Al-Islamiya Wa Adillatuhu. Juz 4 (Damaskus : Dar Al-Fiqr. 2006), 2930

${ }^{21}$ Rachmat Syafei, Fiqh Muamalah,( Bandung : Pustaka setia, 2000), 43 


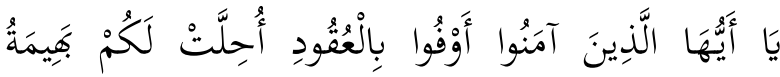

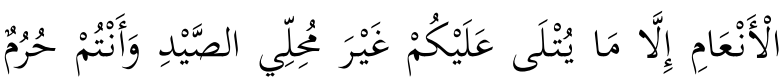$$
\text { إِنَّ اللَّه يَكْكُمُ مَا يُرِيدُ. }
$$

Hai orang-orang yang beriman, penuhilah akad-akad itu. Dihalalkan bagimu binatang ternak, kecuali yang akan dibacakan kepadamu. (Yang demikian itu) dengan tidak menghalalkan berburu ketika kamu sedang mengerjakan haji. Sesungguhnya Allah menetapkan hukum-hukum menurut yang dikehendaki-Nya. ${ }^{22}$

Kata الْعُعُوِ pada surat Al-Maidah diatas merupakan jama' dari kata e عang merupakan suatu bentuk perjanjian yang memiliki makna ikatan yang kuat seperti ucapan "aku mengikat tali dengan tali yang lain" ini merupakan makna etimologi yang memberikan pengertian bahwa akad merupak suatu ikatan yang mengikat satu dengan yang lain. Makna akad disini juga seperti Allah mengikat hambanya dengan syariat yang telah ditetapkan agar dilaksanakan. ${ }^{23}$ dalam tafsir Jalalain dijelaskan bahwa akad harus dipenuhi sebagaimana yang telah diperintahkan dalam agama Islam, adapun perintah yang harus dilaksanakan oleh umat Islam antara lain, yaitu; memenuhi janji, kebenaran dalam akad, niat yang baik dan tidak melewati batas. ${ }^{24}$

Dalam QS. An-Nisa' [4:21] juga disebutkan juga ;

\section{Keluarga,. 106 \\ 22 Kementerian Agama RI. Al-Quran \\ ${ }^{23}$ Muhammad ali as-shabuni, Tafsir Ayat Al-} Ahkam, Juz 1 (Beirut : Dar Kutub Al-Islamiyah, 2001),412-413

${ }^{24}$ Ahmad bin Muhammad As-Sawi, Hasiyat AsSawi 'Ala Tafsir Al-Jalalain, (Beirut : Dar Kutub AlIslamiyah), 353. Baca juga 'Abdurrahman Halaluddin Al-Suyuti, Al-Durru Al-Manstur Fi Tafsir Al-Ma'stur, Juz 3 ( Beirut : Dar Al-Fikr, 2002), 5
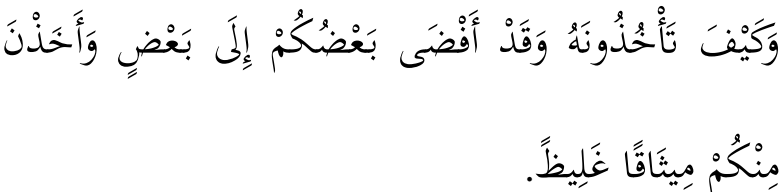

Dan bagaimana kamu akan mengambilnya kembali, padahal sebagian kamu telah bergaul (bercampur) dengan yang lain sebagai suamiisteri. Dan mereka (isteri-isterimu) telah mengambil dari kamu perjanjian yang kuat. ${ }^{25}$

Dalam terminologi hukum Islam makna akad secara khusus didefinisikan sebagai berikut:

ارتباط ايجاب بقبول على وجه مشروع بثبت أثره في محله

Akad adalah pertalian antara ijab dan qabul $^{26}$ yang dibenarkan oleh syara' yang menimbulkan akibat hukum terhadap obyeknya.

Yang dimaksud dengan ايجاب dalam definisi akad adalah ungkapan atau penyataan kehendak melakukan perikatan (akad) oleh suatu pihak, biasanya disebut sebagai pihak pertama. Sedangkan akad nikah adalah rangkaian ijab yang diucapkan oleh wali dan qabul yang diucapkan oleh mempelai pria atau wakilnya disaksikan oleh dua orang saksi. ${ }^{27}$ Dari definisi akad nikah tersebut dapat Keluarga,. 81

25 Kementerian Agama RI. Al-Quran

26 Definisi Ijab menurut Ulama' Hanafiyah adalah penetapan perbuatan tertentu yang menunjukkan keridhaan yang diucapkan oleh orang pertama, baik yang menyerahkan ataupun yang menerima,sedangkan qabul adalah orang yang berkata setelah orang yang mengucapkan ijab, yang menunjukkan keridhaan atas ucapan orang pertama. Namun dikalangan Ulama' selain Hanafiyah berpendapat Ijab adalah pernyataan yang keluar dari orang yang menyerahkan benda, baik dikatakan oleh orang pertama atau kedua sedangkan qabul adalah pernyataan dari orang yang menerima barang. Wahbah Zuhaili, Fiqh Al-Islamiya Wa Adillatuhu.,2918

27 Syamsuddin Muhammad Abi Abbas, Nihayatu Al-Muhtaj Ila Syarhi Al-Manhaj, (Bairut : Dar Al-Kitab Al-Ilmiyah, 1993),209 
dipahami bahwa rukun nikah mencakup dari definisi akad nikah itu sendiri yaitu : Pertama, Adanya mempelai laki-laki dan wanita. Kedua, Adanya wali. Ketiga, Dua orang saksi dan keempat adalah shighat nikah. ${ }^{28}$ Para ulama syafi'iyah dalam perihal qabul boleh diwakilkan seperti ucapan " aku terima nikahnya untuk fulan". Dalam hal ini dibolehkan. ${ }^{29}$

\section{Syarat-Syarat Akad Nikah}

Akad nikah didasari atas suka sama suka, atau rela sama rela. Oleh karena perasaan rela sama rela itu tersebunyi, maka sebagai manifestasinya adalah ijab dan qabul. Oleh karena itu, ijab dan qabul adalah unsur mendasar bagi keabsahan akad nikah. ${ }^{30}$ Akad nikah harus berkonotasi jala'ul ma'na yaitu dinyatakan dengan ungkapan yang jelas dan pasti maknanya, sehingga dapat dipahami oleh saksi apa yang diucapkan oleh wali dari mempelai perempuan (ijab) dan mempelai laki-laki $(q a b u l){ }^{31}$ Oleh karena itu, akad merupakan tahap awal sebelum melakukan pernikahan. Hal ini untuk meyakinkan dan memperjelas status sesudahnya, dapat

\footnotetext{
${ }^{28}$ Zainuddin bin 'Abdul 'Aziz Al-Malibary, Fathu Al-Mu'in. 203

${ }^{29}$ Yahya bin Syarif Abi Zakariya Al-Nawawi, Raudhatu Al-Thalibin, Juz 6 (Beirut : Dar Al-Fikr, 2005),70

30 Satria Effendi, Problematika Hukum Keluarga Islam Kontenporer, (Jakarta : Kencana, 2004), 3

${ }^{31}$ Dalam lafald ijab harus menggunakan katakata yang merepresentasikan kata nikah seperti ucapan "akunikahkan kamu" bisa dengan menggunakan fi'il madhi dan fi'il mudhari' seperti lafald "تزوجت"atau "النكحت". Dan tidak sah nikah hanya dengan ucapan kinayah (sindiran) dan dengan bahasa yang tidak mengandung makna nikah. Adapun dalam mengucapkan qabul boleh dengan menggunakan ucapan " qabiltu”, "wafaqtu”, " afdhaitu” nafadztu”. Baca Naji Hasan Si'afin. Al-Minhal Al-'Adhbu AsSyafi'i Fi Fiqh Al-Madhab Al-Syafi'i, Juz 2 (Beirut : : Dar Kutub Al-Islamiyah,2001), 61. Ali yusuf As-Subki, Fiqh Keluarga,.101. Baca juga Muhammad AlMarshafi, Hasiyah Al-Bajuru 'Ala Syarh Minhaj AlTullab, Juz 3 (Beirut : Dar al-fikr, 2002),334
}

dipahami bahwa akad secara filosofi memiliki ikatan yang kuat baik lahir dan batin.

Dalam konsep hukum Islam (syari'at) yang berhak mengakadkan nikah yaitu wali laki-laki dari pihak perempuan ke atas yaitu ayah, kakek, kemudian saudara laki-laki seayah seibu, kemudian saudara laki-laki seayah, anak laki-laki dari saudara laki-laki seayah seibu, anak laki-laki dari saudara lakilaki seayah, kemudian paman dan terakhir anak laki-laki dari paman, ketentuan urutan ini harus terjaga tidak bisa saling melewati. ${ }^{32}$

Syarat akad nikah menurut para ulama ada empat (4) hal yang harus dipenuhi antara lain $:^{33}$

1. Dua orang yang berakad telah tamyiz, jika salah satunya gila atau tidak tamyiz maka pernikahan tidak sah.

2. Kesatuan tempat ijab dan Qabul dengan artian tidak terpisah antara ijab dan qabul, sehingga tidak ada halangan antara mempelai.

3. Kesempurnaan ijab dan Qabul, dalam artian keselarasan antara ijab dan Qabul.

4. Masing-masing orang yang berakad memahami dan mendengan maksud dari akad pernikahan. Meskipun masingmasing dari mereka tidak memahami arti kosa kata tersebut. $^{34}$

32 Ibnu Rushdi, Bidayatu Al-Mujtahid Wa Nihayatu Al-Muqtashid, ( Beirut : Maktabah Al-Syuruq Al-Dauliyah, 2004),382-384. Baca juga Zainuddin bin 'Abdul 'Aziz Al-Malibary, Fathu Al-Mu'in, 202.

${ }_{33}$ Ali Yusuf As-Subki, Fiqh Keluarga,.100-101

34 Sebagian yang fanatik dengan bahasa arab kebanyakan mereka mengakadkan dengan bahasa arab meskipun para mempelai tidak paham arti dari ucapan tersebut, karena yang terpenting yaitu kejelasan dan kebenaran ucapan serta memahami tujuan dari ucapan tersebut. 
Berhubungan dengan tempat pelaksanaannya, Islam tidak mengatur secara spesifik, hanya saja sunnah jika ingin melangsungkan akad nikah dilakukan di tempat-tempat yang baik seperti di mesjid, sebagimana berdasarkan hadis Nabi SAW :

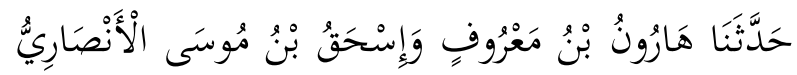

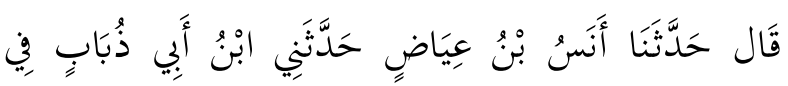

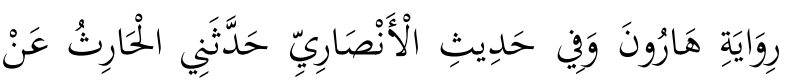

عَبْدِ الرَّمَمَنِ بْنِ مِهْرَانَ عَنْ أَبِي هُرَيْرَة أَنَّ رَسُولَ اللَّهِ صَلَّى

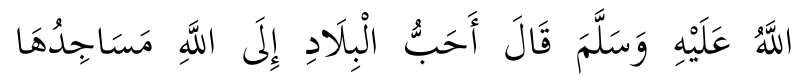

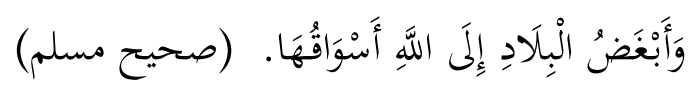

Telah bercerita kepada kami Hassrun bin Ma'ruf dan Ishaq bin Musa Al-Anshari berkata. Telah bercerita kepada kami Anas bin 'Iyad telah bercerita kepada kami Abi Dubab dalam riwayat Harun dan didalam hadis AlAnshar telah bercerita kepadaku Al-Harits dari 'Abduurrahman bin Mihran dari Abi Hurairah bahwa bahwasannya Rasulullah bersabda : "Tempat yang paling dicintai oleh Allah adalah masjid dan tempat yang paling dibenci alloh adalah pasar". (HR. Muslim). ${ }^{35}$

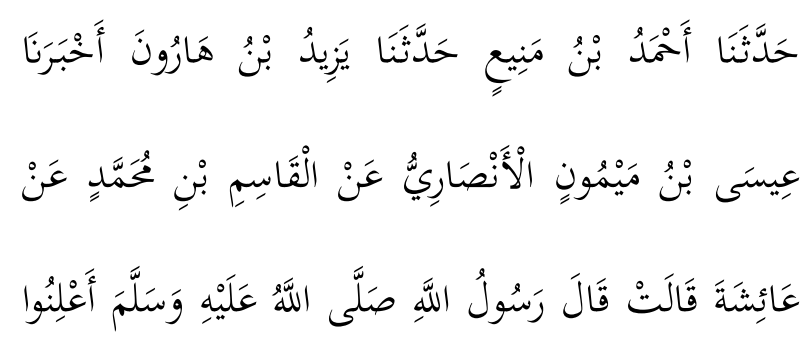

${ }^{35}$ Yahya bin Syarif An-Nawawi, Shahih Muslim Bisyarhi An-Nawawi, ( Al-Qahirah :Dar Al-Manar, 2002),303
هَذَا النِّكاحَ وَاجْعَلُوهُه فِي الْمَسَاجِدِ وَاضْرِبُوا عَلَيْهِ. (سنن

$$
\text { (الترمذي) }
$$

Telah bercerita kepada kami Ahmad bin Mani' telah bercerita kepada kami Yazid bin Harun telah mengabarkan kepada kami 'Isa bin Maimun Al-Anshari dari Al-Qasim bin Muhammad dari 'Aisyah berkata. Rasul SAW bersabda " siarkanlah pernikahan ini, dan adakanlah dimasjid-masjid dan tabuhlah gendang-gendang". (HR. Turmudzi) ${ }^{36}$

Dapat dipahamai bahwa pada dasarnya akad merupakan rangkaian antara ijab dan qabul yang wajib diucapkan secara lisan. Bagi orang bisu sah melakukan ijab dan qabul dengan isyarat yang dapat dipahami oleh saksi dan orang yang hadir ditempat tersebut. Ijab dan qabul dilakukan di dalam satu majlis dan tidak boleh ada jarak yang lama atau yang merusak kesatuan dari ijab dan qabul. ${ }^{37} \mathrm{Hal}$ ini berbeda dengan imam Hanafi yang membolehkan ijab dan qabul dengan adanya jarak asalkan masih dalam satu majlis. ${ }^{38}$

\section{Akad Nikah Dalam Perspektif UU Perkawinan dan KHI}

Salah satu fenomena yang muncul di dunia Islam pada abad 20 adalah upaya

3636 Berkata Abu 'Isa bahwa hadis ini gharib hasan didalam pembahasan bab ini bahwa 'Isa bin Maimun Al-Anshari dha'if. Dan Abi Najih berpendapat bahwa dia stiqah. Dilihat dari sisi hukum maka hal itu diperbolahkan selama tidak dibarengi dengan keyakinan bahwa hal itu adalah wajib karena haditsnya lemah dan tetap menjaga adab-adab syar'i didalam mengadakan acara walimah tersebut. Tetapi jika dipadukan dengan pendapat Imam Syafi'i hadis dhaif bisa diamalkan untuk kesempurnaan amal. lihat Basyar Ma'ruf, Al-Jami' Al-Kabir, Juz 2 (Bairut : Dar AlGharbi Al-Islami, 1998), 384-385

37 KHI Pasal 27 menyatakan bahwa Ijab dan qabul antara wali dan calon mempelai pria harus jelas beruntun dan tidak berselang waktu.

38 Abdurahman Ghozali, Fiqh Munakahat, (Jakarta : Kencana, 2010),57 
pembaruan hukum keluarga yang dilakukan oleh negara-negara yang berpenduduk mayoritas muslim. Hal ini dilakukan sebagai respon terhadap dinamika yang terjadi di tengah masyarakat. Setidaknya ada tiga hal yang menjadi tujuan dilakukannya pembaruan hukum keluarga Islam, yaitu sebagai upaya unifikasi hukum, mengangkat status perempuan, dan merespon perkembangan dan tuntutan zaman, karena konsep fiqh tradisional dianggap kurang mampu memberikan solusi terhadap permasalahan yang ada. ${ }^{39}$

Berbicara tentang akad nikah dapat dilihat bahwa dalam UU No 1 Tahun 1974 Tentang Perkawinan tidak menjelaskan tentang akad nikah. Ketentuan yang diatur dalam UU No 1 Tahun 1947 hanya secara umum saja tidak menyangkut permasalahan hukum nikah secara substantif. Hal ini berbeda dengan KHI yang disebut sebagai fiqh indonesia yang mengatur perihal pernikahan secara spesifik.

Dalam KHI dijelaskan pada ketentuan umum huruf $\mathrm{c}$ bahwa akad nikah ialah rangkaian ijab yang diucapkan oleh wali dan qabul yang diucapkan oleh mempelai pria atau wakilnya disaksikan oleh dua orang saksi. Dari ketentuan umum tersebut telah mancakup dari aspek rukun nikah.

Pasal 28 dalam KHI dinyatakan juga bahwa Akad nikah dilaksanakan sendiri secara pribadi oleh wali nikah yang bersangkutan. Wali nikah mewakilkan kepada orang lain. Dalam konteks ini jika wali nikah

39 Didunia yang mayoritas Islam untuk mereformasi hukum keluarga lebih mengadopsi hukum yang berkembang di dunia barat, seperti Turki, Lebanon, Yordania, Tunisia serta Negara mayoritas Islam lainnya. Baca N.J. Coulson, A History of Islamic law, (Edinburgh : Edinburgh University Press,1964),216-217. Baca juga Amir Mu'allim. Yusdani, Konfigurasi Pemikiran Hukum Islam, (Yogyakarta : UII Press,2001),1 tidak mampu untuk menjadi wali dalam mengakadkan nikah. Maka, dapat diwakilkan kepada wali hakim, sebagaimana bunyi Pasal 20 Ayat (2) menyatakan bahwa Wali nikah terdiri dari Wali nasab ${ }^{40}$ dan Wali hakim. ${ }^{41}$ Dalam KHI juga dijelaskan secara teknis bahwa yang mngucapkan qabul adalah calon mempelai pria sendiri. Namun, dalam hal-hal tertentu ucapan qabul nikah dapat diwakilkan kepada pria lain dengan ketentuan calon mempelai pria memberi kuasa yang tegas secara tertulis bahwa penerimaan wakil atas akad nikah itu adalah untuk mempelai pria.

40 Pasal 21 dijelaskan bahwa :

(1) Wali nasab terdiri dari empat kelompok dalam urutan kedudukan, kelompok yang satu didahulukan dan kelompok yang lain sesuai erat tidaknya susunan kekerabatan dengan calon mempelai wanita.

Pertama, kelompok kerabat laki-laki garis lurus keatas yakni ayah, kakek dari pihak ayah dan seterusnya.

Kedua, kelompok kerabat saudara laki-laki kandung atau saudara laki-laki seayah, dan keturunan laki-laki mereka.

Ketiga, kelompok kerabat paman, yakni saudara laki-laki kandung ayah, saudara seayah dan keturunan laki-laki mereka.

Keempat, kelompok saudara laki-laki kandung kakek, saudara laki-laki seayah dan keturunan laki-laki mereka.

(2) Apabila dalam satu kelompok wali nikah terdapat beberapa orang yang sama-sama berhak menjadi wali, maka yang paling berhak menjadi wali ialah yang lebih dekat derajat kekerabatannya dengan calon mempelai wanita.

(3) Apabila dalam satu kelompok sama derajat kekerabatan maka yang paling berhak menjadi wali nikah ialah kerabat kandung dari kerabat yang seayah.

(4) Apabila dalam satu kelompok, derajat kekerabatannya sama yakni sama-sama derajat kandung atau sama-sama dengan kerabat seayah, mereka sama-sama berhak menjadi wali nikah, dengan mengutamakan yang lebih tua dan memenuhi syarat-syarat wali.

41 Pasal 23 ayat (1) Wali hakim baru dapat bertindak sebagai wali nikah apabila wali nasab tidak ada atau tidak mungkin menghadirkannya atau tidak diketahui tempat tinggalnya atau gaib atau adlal atau enggan. 


\section{Aqad Nikah di KUA Dan Di Luar KUA}

Ketentuan pencatatan nikah merupakan suatu hal yang harus dilakukan bagi setiap orang yang akan menikah. Ketentuan pencatatan nikah dijelaskan dalam UU No 1 Tahun 1974 Tentang Perkawinan. Dalam Pasal 2 ayat (2) yang menjelaskan bahwa Tiap-tiap perkawinan dicatat menurut peraturan perundang-undangan yang berlaku. ketentuan ini bukan merupakan syarat sahnya nikah. Ketentuan ini merupakan bukti yang menunjukan kejelasan atas status pernikahan seseorang.

Islam juga memandang bahwa pencatatan pernikahan merupakan suatu keharusan, karena pencatatan nikah akan memberikan dampak yang berbahanya bagi suami dan istri. Kekuatan dari pencatatan nikah juga untuk dapat membuktikan bahwa pernikahan yang dilakukan diakui oleh Negara serta kejelasan anak dari hasil pernikahan tersebut. Akan tetapi, pencatatan nikah tidak termasuk kedalam rukun dan syarat nikah. Melihat kemudharatan yang lebih besar. Maka, pencatatan nikah dirasakan sangat penting demi menjamin hak hukum suami dan istri.

Dari beberapa aspek yang dapat dilihat berdasarkan tujuan dari pencatatan nikah adalah demi menjamin hak si istri dan suami serta menjami status anak dari hasil perkawinan tersebut. Maka, pencatatan nikah meskipun bukan dari bagian pernikahan tetapi harus dilakukan. Berdasarkan kaedah ;

$$
\text { درء المفا سد و جلب المصا لح }
$$

"Menolak ke mufsadatan dan mengambil kemaslahatan"

\section{"Kemudaratan/kerusakan harus dihilangkan"}

Kedua kaedah tersebut cukup mewakili bahwa untuk menghilangkan kemudharatan yang timbul akibat pencatan nikah. Maka, pencatatan nikah dirasakan perlu untuk dilakukan oleh pihak mempelai.

Pada dasarnya tidak ada perbedaan pencatatan nikah di KUA dan di luar KUA. Hanya saja, dalam praktiknya perbedaan tersebut terlihat dari besar kecilnya pengeluaran uang yang akan di keluarkan bagi pihak yang ingin menikah. Pemerintah tidak membatasi terkait dengan apakah pencatatan nikah harus dilakukan di KUA atau di Luar KUA. pencatatan nikah di luar KUA secara otomatis pihak mempelai harus mnghadirkan pihak KUA di tempat acara. Maka, secara tidak langsung pihak mempelai setidaknya menyiapkan sarana yang dibutuhkan oleh KUA. berbeda lagi jika pencatatan dilakukan di KUA yang menyiapkan fasilitas pernikahan seperti tempat adalah KUA. Pemerintah tidak membatasi tempat pencatatan nikah, karena yang terpenting yaitu bahwa pihak yang berkewajiban mencatatat peristiwa nikah yaitu PPN sebagaimana yang dijelaskan dalam Pasal 2 PMA No 11 Tahun 2007 Tentang Pencatatan Nikah bahwa Pegawai Pencatat Nikah yang selanjutnya disebut PPN adalah pejabat yang melakukan pemeriksaan persyaratan, pengawasan dan pencatatan peristiwa nikah/rujuk, pendaftaran cerai talak, cerai gugat, dan melakukan bimbingan perkawinan. ${ }^{42}$

\section{DAFTAR PUSTAKA}

${ }^{42}$ Lihat Peraturan Menteri Agama No 11 Tahun
2007 Tentang Pencatatan Nikah pada Pasal 2.

Aqad Nikah Pespektif Fiqh Dan Kompilasi Hukum Islam | 32 
'Abdu Al-Baqi, Muhammad Fua'd, Shahih Muslim, Juz 2 ( Indonesia : Maktabah Dahlan, $\mathrm{tt}$ )

A.W. Munawwir, Kamus Al-Munawwir Indonesia Dan Arab, (Surabaya : Pustaka Progressif, 2007)

Abi Abbas, Syamsuddin Muhammad, Nihayatu Al-Muhtaj Ila Syarhi AlManhaj, (Bairut : Dar Al-Kitab AlIlmiyah, 1993),209

Ahmad bin Muhammad As-Sawi, Hasiyat AsSawi 'Ala Tafsir Al-Jalalain, (Beirut : Dar Kutub Al-Islamiyah)

Al-'Asqalani, Ibn Hajar, Bulughul Maram, ( Beirut : Dar Al-Kutub Al-Islamiyah, 2002)

Al-Andalisia, Ibnu Rusydi Al-Qurtubi, Bidayatul Mujtahid Wa Nihayatu AlMuqashid, (Mesir : Maktabah AlSyuruqu Al-Dauliah, 2004), 380

Al-Bukhari, 'Abdullah Muhammad bin Isma'il, Shahih Al-Bukhari, Juz 3 ( Bairut : Dar Al-Fikr, 1981)

Al-Ghazaly, Abd, Rahman Fikih Munakahat, (Jakarta:Kencana, 2006),

Al-Jazairi , Abu Bakr Al-Jabir, Minhaju AlMuslim, (Madinah : Maktabah Al-Ulum wa Al-Hikam, 2012)

Al-Jaziri, 'Abdurahman, Kitab Al-fIqh 'Ala Al-Mazdahib Al-Arba'ah, ( Beirut : Dar Al-Kutub Al-'Ilmiyah, 1986)

Al-Malibari, Zainuddin bin 'Abdul 'Aziz, Fathul Mu'in, (Jakarta : Dar Al-Kutub Al-Islamiyah,2010)

Al-Nawawi, Yahya bin Syarif Abi Zakariya, Raudhatu Al-Thalibin, Juz 6 (Beirut : Dar Al-Fikr, 2005)

Al-Ramli, Muhammad bin Ahmad, Ghayah Al-Bayan Syarh Zubad Ibn Raslan,( Beirut : Dar Al-Kutub Al-Islamiyah, 2012)
Al-Suyuti, 'Abdurrahman Halaluddin, $A l$ Durru Al-Manstur Fi Tafsir Al-Ma'stur, Juz 3 ( Beirut : Dar Al-Fikr, 2002)

As-shabuni, Muhammad ali, Tafsir Ayat AlAhkam, Juz 1 (Beirut : Dar Kutub AlIslamiyah, 2001)

As-Subki, Ali Yusuf, Fiqh Keluarga, diterjemahkan oleh Nur Khizim. (Jakarta : AMZAH, 2010)

Effendi,Satria, Problematika Hukum Keluarga Islam Kontenporer, (Jakarta : Kencana, 2004)

Ghozali, Abdurahman, Figh Munakahat, (Jakarta : Kencana, 2010)

Kementerian Agama RI. Al-Quran Keluarga, ( Bandung : Fitrah Rabbani, 2009)

Ma'ruf, Basyar, Al-Jami' Al-Kabir, Juz 2 (Bairut : Dar Al-Gharbi Al-Islami, 1998)

Mu'allim, Amir, Yusdani, Konfigurasi Pemikiran Hukum Islam, (Yogyakarta : UII Press, 2001)

N.J. Coulson, A History of Islamic law, (Edinburgh : Edinburgh University Press, 1964)

Shiddieq, Umay M. Dja'far, Indahnya Keluarga Sakinah Dalam Naungan AlQur'an dan Sunnah, (Jakarta: Zakia Press, 2004)

Si'afin. Naji Hasan, Al-Minhal Al-'Adhbu AsSyafi'i Fi Fiqh Al-Madhab Al-Syafi'i, Juz 2 (Beirut : : Dar Kutub AlIslamiyah,2001)

Syafei, Rachmat, Fiqh Muamalah,( Bandung : Pustaka setia, 2000)

Syarifuddin, Amir , Hukum Perkawinan Islam Di Indonesia. (Jakarta: Kencana. 2007)

Yahya bin Syarif An-Nawawi, Shahih Muslim Bisyarhi An-Nawawi, ( Al-Qahirah :Dar Al-Manar, 2002),

Zuhaili,Wahbah, Fiqh Al-Islamiya Wa Adillatuhu. Juz 4 (Damaskus : Dar AlFiqr. 2006) 
UU No. 1 Tahun 1974 Tentang Perkawinan

Kompilasi Hukum Islam

Peraturan Menteri Agama No 11 Tahun 2007

Tentang Pencatatan Nikah 